\title{
Phytotoxic Effect of Brachiaria decumbens Extract on the Development of Eucalyptus urograndis Seedlings
}

\author{
Fernando Luiz da Cruz Balena ${ }^{1}$, Reginaldo Ferreira Santos ${ }^{1}$, Doglas Bassegio ${ }^{1}$, Deonir Secco ${ }^{1}$, \\ Luciene Kazue Tokura ${ }^{1}$, Leonardo da Silva Reis ${ }^{2}$, Bruna de Villa ${ }^{1}$ \& Chaiane Bassegio ${ }^{1}$ \\ ${ }^{1}$ Graduation Program, Master's in Engineering of Energy in Agriculture, State University of West Paraná, \\ Cascavel, Paraná, Brazil \\ ${ }^{2}$ University Center of the Assis Gurgacz Foundation, Cascavel, Paraná, Brazil \\ Correspondence: Fernando Luiz da Cruz Balena, Graduation Program, Master's in Engineering of Energy in \\ Agriculture, State University of West Paraná, Rua Universitária, 2069-Jardim Universitário, CEP: 85819-110, \\ Cascavel, Paraná, Brazil. Tel: 55-499-9970-6774. E-mail: fernando.balena@unochapeco.edu.br
}

Received: May 16, 2019

doi:10.5539/jas.v11n16p46
Accepted: July 14, 2019 Online Published: September 30, 2019

URL: https://doi.org/10.5539/jas.v11n16p46

\begin{abstract}
The objective of this work was to evaluate the phytotoxic effect of Brachiaria decumbens Stapf. on the morphometry of Eucalyptus urograndis plants, genetically modified hybrid of Eucalyptus urophylla S. T. Blake $\times$ Eucalyptus grandis W. Hill ex Maiden. Pots containing the eucalyptus plants were conditioned in protected environments in a completely randomized experimental design. The treatments were composed of aqueous extract of Brachiaria decumbens grass at different concentrations: $0 \%$ (control, distilled water only), $20 \%, 40 \%$, $60 \%, 80 \%$ and $100 \%(\mathrm{~g} / \mathrm{L})$. On day 30 of the experiment, the following morphological parameters of the plants were evaluated: aerial part height, diameter of stem, aerial dry mass, root dry mass, total dry mass, and robustness index. The data were submitted to analysis of variance at the $5 \%$ level of significance, and a regression equation was constructed for the quantitative treatments. The results indicated that the Brachiaria decumbens grass extract did not have an inhibitory effect on aerial part height and robustness index. However, the extract at concentrations higher than $20 \%$ had negative effects on root dry mass, aerial dry mass, and total dry mass. For the diameter of the stem, only concentrations above $60 \%$ had an inhibitory effect.
\end{abstract}

Keywords: aqueous extract, morphological parameters, inhibition

\section{Introduction}

In recent years, the silvopastoral systems (SPS), one of the modalities of agroforestry systems, have attracted a great number of followers in the search to promote sustainable land use. Because it encompasses more than one productive component, special attention should be given to the planning phase. One of the factors that merits attention is called allelopathic effect (Plevich et al., 2019).

Sustainability in Brazilian agriculture is related to the integration of production systems, such as crop-livestock-forest integration (ILPF) and low-carbon agriculture (ABC Plan) (Kluthcouski et al., 2013). Agricultural models aimed at the diversification of production, increase and better distribution of income over time, soil and water conservation, thermal comfort for animals, improvement of forage nutritional value and others are obtained through agroforestry (Oliveira Neto \& Paiva, 2010). The SPS is the intentional combination of trees, pastures and animals in the same area and at the same time, managed in an integrated way (Silva et al., 2010), and has been become more widely used in recent years.

The composition of these components, as well as their spatial and temporal arrangement, can promote innumerable interactions, both ecological and economic, and that must be strategically analyzed in planning, implementing, and managing the system (Oliveira Neto \& Paiva, 2010).

Adopting agroforestry systems means choosing ecologically and economically suitable species for a desired purpose (Simão et al., 2012). In these productive systems, many peculiarities inherent in the interaction itself and/or influence that occurs between plants should be considered. The term allelopathy was created by Molisch and is derived from the union of the Greek words alleton and pathos, meaning mutual and mischief, respectively (Molisch, 1937). 
Allelopathy occurs in nature as a mechanism by which some plants, algae, bacteria or fungi can interfere with nearby species or biological systems, affecting their growth and/or development in a beneficial, malicious or neutral way. Such interactions occur due to the release of chemical substances (allelochemicals) from secondary metabolism in organisms that affect other community components (International Allelopathy Society, 2017).

Allelopathic substances are released from plant tissues by volatilization, leaching, root exudation, and the decomposition of plant residues (Larcher, 2000). It is more common for neighboring plants to interact in a negative than a positive way, so that the emergence and/or growth of one or both of them is inhibited (Pires \& Oliveira, 2011).

Finding the phytotoxic potential with focus allelopathic in plants is the objective of many researches, such as those developed by Cremonez et al. (2013), Silva et al. (2015), Rizzi et al. (2016), Silveira et al. (2016), Plevich et al. (2019); therefore, are natural methods that can be used as weed management strategies. Potentially allelopathic species that benefit others can be used to improve sustainable agriculture control methods, such as no-tillage, rotation, and crop consortium (Bonamigo et al., 2013).

Important forages such as species of the family Poaceae (especially Brachiaria decumbens) have become problematic in commercial plantations of Eucalyptus spp. and Pinus spp., not only because they are highly aggressive and difficult to control, but also because of the increase in exploitation of old pastures by reforestation companies (Toledo, 1998). In addition, the forester should also consider the potential negative allelopathic effect of $B$. decumbens' root exudates, already proven to influence neotropical tree seedlings (Silva et al., 2017).

Forest species, like other crops, are subject to neighboring plant interference, which leads to qualitative and quantitative decreases in their production, becoming one of the major problems in the implementation and maintenance of eucalyptus forests (Toledo et al., 1999). For example, in the region of Botucatu (SP, Brazil) there was a reduction in the initial development of eucalyptus ( $E$. grandis) seedlings planted in old pastures of $B$. decumbens (Souza et al., 2003). The coexistence between eucalyptus and brachiaria grass has been showing negative interference on the growth of both species (Assis et al., 2015).

On the basis of this information and with the new demands that are arising to improve production systems, it is important to evaluate possible allelopathic effects, especially when consortium cultivation systems occur-for example, the forest component (eucalyptus plants) and pasture (brachiaria grass). This can prevent producers from exhibiting allelopathic effects in the search for the best production management.

In this context, the present work aimed to study the possible phytotoxic effect of an aqueous extract of Brachiaria decumbens Stapf. on the initial development of Eucalyptus urograndis seedlings.

\section{Material and Methods}

\subsection{Location of the Experiment and Treatments}

The studies were conducted in the experimental area of the State University of the West of Paraná (UNIOESTE), Campus of Cascavel, Paraná, Brazil, in a greenhouse model with a thermorephore sombrite, located at $02^{\circ} 46^{\prime}$ South latitude and $77^{\circ} 39^{\prime}$ West longitude, average altitude 700 meters. The experiment was conducted between April and May 2018, totaling 30 days.

Sixty seedlings of clone AEC 144, a genetically modified hybrid of Eucalyptus urophylla $\times$ Eucalyptus grandis, were obtained from a regional nursery, 120 days after staking and already in the dispatch phase. These, in turn, were transplanted into vessels with a dimension of $0.2 \mathrm{~m}$ in height and $0.2 \mathrm{~m}$ in diameter, with a volume capacity of $6.28 \mathrm{dm}^{3}$ each. One plant was transplanted per pot.

The pots were filled with substrate at a ratio of 1:1 (v/v), that is, 50\% subsoil (dystrophic Red Latosol) mixed with $50 \%$ humus (Húmisto $囚$ ) composed of earthworm humus, charcoal, pine bark ground, limestone, and vermiculite (Gonçalves et al., 2013).

For the preparation of the extract, Brachiaria decumbens plants were collected near the experimental unit of the university campus. The aerial part of the plants was conditioned in Kraft paper bags and kept in an oven with forced air circulation at $65{ }^{\circ} \mathrm{C}$ until a constant weight was achieved. Afterwards, it was ground in a Willey type mill using a 20 mesh sieve.

The aqueous extract was obtained by adding the crushed dry matter of Brachiaria decumbens to distilled water. This mixture was homogenized at different concentrations, according to the ratio of solute mass (Brachiaria decumbens crushed dry matter) to volume of the solution (distilled water, in liters): $0 \%$ (control), $20 \%, 40 \%$, $60 \%, 80 \%$ and $100 \%(\mathrm{~g} / \mathrm{L})$. 
The vessels containing the eucalyptus seedlings were placed in a protected environment arranged in a completely randomized experimental design (CRD), with ten replicates for each of the six treatments.

The aqueous extract was applied directly to the vessels at different concentrations for each treatment on the first day of implantation of the experiment. The treatment with $0 \%$ extract (control) received only distilled water. Throughout the experiment, irrigation needs were monitored daily to maintain the field capacity of the substrate used. To avoid possible losses of water by percolation, the vessels were conditioned under trays with no drains.

On the thirtieth day of the experiment, morphological data were collected from eucalyptus plants, such as: aerial part height (H), diameter of stem (D), aerial dry mass (DMA), root dry mass (DMR), total dry mass (DMT), and robustness index (IR).

The height of the aerial part was measured from the substrate level to the apical meristem using a ruler graduated in millimeters. The collection diameter was measured in millimeters $(\mathrm{mm})$ at the substrate level with the aid of a digital caliper. To determine DMA and DMR, root and aerial parts were separated from the plants, which were then conditioned in a Kraft paper bag, duly identified and oven dried with forced air circulation at $65{ }^{\circ} \mathrm{C}$ until reaching constant weight; the weighing was done with the aid of a semi-analytical electronic scale, with divisions of $0.01 \mathrm{~g}$. The DMT was obtained by adding the DMA and DMR.

The robustness index was obtained by dividing the height of the aerial part by the diameter of stem of the seedlings (Santos et al., 2017). The IR is an absolute value, with no units, and is considered a precise morphological characteristic, as it gives information about how thin the molt is (Gomes \& Paiva, 2004).

\subsection{Statistical Analysis of the Data}

These parameters were submitted for analysis of variance by the Snedecor F-test (Devore, 2006). Initially the assumptions of the model were verified using the Bartlett test for homogeneity of variances and Shapiro-Wilk test for normality. The effect of the extract concentrations on the morphological characteristics of the plants was evaluated by adjusting the regression equation. Analyses were performed using the procedures available in SISVAR software 5.6 (Ferreira, 2010).

\section{Results and Discussion}

The extract of brachiaria grass not influenced the eucalyptus plant's height of the aerial part $(\mathrm{H})$ and index of robustness (IR), indicating that there was no response by the eucalyptus plants to the different levels of extract used in this study.

However, there was a statistically significant difference among the following phenotypic variables: diameter of stem (D), root dry mass (DMR), aerial dry mass (DMA), and total dry mass (DMT). Therefore, the different concentrations of extract had an effect on these variables and consequently on the development of the eucalyptus seedlings (Table 1).

Table 1. Experimental F-test and coefficient of variation (C.V.) for Eucalyptus urograndis plants treated with different concentrations of Brachiaria decumbens grass extract, Cascavel-PR 2018

\begin{tabular}{lllllll}
\hline \multirow{2}{*}{ Treatment } & IR & $\mathrm{H}(\mathrm{cm})$ & $\mathrm{D}(\mathrm{mm})$ & \multicolumn{3}{c}{ Dry mass $(\mathrm{g})$} \\
\cline { 5 - 7 } & & & & Root & Aerial part & Total \\
\hline $\mathrm{F}_{\mathrm{c}}$ & $0.80^{\mathrm{NS}}$ & $0.93^{\mathrm{NS}}$ & $2.92^{*}$ & $5.05^{* *}$ & $3.65^{* *}$ & $4.50^{* *}$ \\
$\mathrm{P}_{\mathrm{r}}>\mathrm{F}_{\mathrm{c}}$ & 0.55 & 0.47 & 0.02 & 0.00 & 0.00 & 0.00 \\
C.V. $(\%)$ & 11.42 & 9.38 & 6.38 & 20.42 & 16.62 & 16.03 \\
\hline
\end{tabular}

Note. $\mathrm{H}=$ height aerial part; $\mathrm{D}=$ diameter of stem; DMA $=$ aerial dry mass; $\mathrm{DMR}=$ root dry mass; $\mathrm{DMT}=$ total dry mass; IR $=$ index of robustness. $* *$ Significant at the $1 \%$ probability level $(P<0.01) . *$ Significant at the $5 \%$ probability level $(0.01 \leq P<0.05)$. NS $=$ not significant $(0.05 \leq P)$.

Table 1 shows that the coefficients of experimental variation diverged from $6.38 \%$ (for D variable) to $20.42 \%$ (for DMR variable). However, coefficients of variation below $10 \%$ are considered low, and those between 10 and $20 \%$ are average (Pimentel-Gomes, 1987).

For the behavior of the mean values (Table 2), the $100 \%(\mathrm{~g} / \mathrm{L})$ concentration of extract compared to the control caused a decrease of $20.55 \%$ in the DMT of the seedlings. A similar trend was found for DMA and DMR, where the extract at $100 \%$ decreased the average values by $19.23 \%$ and $20.83 \%$, respectively, compared to the control. 
Table 2. Mean values for Eucalyptus urograndis plants treated with different concentrations of Brachiaria decumbens grass extract under protected environment conditions for 30 days, Cascavel-PR 2018

\begin{tabular}{lllllll}
\hline Treat. & $\mathrm{IR}$ & $\%$ & $\mathrm{H}\left(\mathrm{cm} \mathrm{plant}^{-1}\right)$ & $\%$ & $\mathrm{D}\left(\mathrm{mm} \mathrm{plant}^{-1}\right)$ & $\%$ \\
\hline $0 \%$ & $13.61 \pm 1.67^{1}$ & - & $62.10 \pm 4.84$ & - & $4.59 \pm 0.25$ & - \\
$20 \%$ & $12.79 \pm 1.51$ & 93.98 & $59.40 \pm 7.49$ & 95.65 & $4.65 \pm 0.29$ & 101.31 \\
$40 \%$ & $12.75 \pm 1.69$ & 93.68 & $61.60 \pm 8.12$ & 99.19 & $4.85 \pm 0.35$ & 105.66 \\
$60 \%$ & $13.28 \pm 1.27$ & 97.58 & $63.65 \pm 4.14$ & 102.50 & $4.81 \pm 0.29$ & 104.79 \\
$80 \%$ & $12.83 \pm 1.37$ & 94.27 & $59.40 \pm 4.75$ & 95.65 & $4.65 \pm 0.21$ & 101.31 \\
$100 \%$ & $13.67 \pm 1.47$ & 100.44 & $59.75 \pm 3.32$ & 96.22 & $4.40 \pm 0.37$ & 95.86 \\
\hline Treat. & DMR $\left(\mathrm{g} \mathrm{plant}^{-1}\right)$ & $\%$ & DMA $\left(\mathrm{g} \mathrm{plant}^{-1}\right)$ & $\%$ & $\mathrm{DMT}\left(\mathrm{g} \mathrm{plant}^{-1}\right)$ & $\%$ \\
\hline $0 \%$ & $1.20 \pm 0.26$ & - & $4.94 \pm 0.65$ & - & $6.13 \pm 0.83$ & - \\
$20 \%$ & $1.31 \pm 0.20$ & 109.17 & $4.69 \pm 0.77$ & 94.94 & $6.00 \pm 0.85$ & 97.88 \\
$40 \%$ & $1.31 \pm 0.26$ & 109.17 & $4.89 \pm 0.89$ & 98.99 & $6.20 \pm 1.08$ & 101.14 \\
$60 \%$ & $1.17 \pm 0.21$ & 97.50 & $4.75 \pm 0.72$ & 96.15 & $5.92 \pm 0.89$ & 96.57 \\
$80 \%$ & $0.94 \pm 0.24$ & 78.33 & $3.92 \pm 0.77$ & 79.35 & $4.87 \pm 0.92$ & 79.45 \\
$100 \%$ & $0.95 \pm 0.22$ & 79.17 & $3.99 \pm 0.70$ & 80.77 & $4.93 \pm 0.87$ & 80.42 \\
\hline
\end{tabular}

Note. $\mathrm{H}=$ height aerial part; $\mathrm{D}=$ diameter of stem; $\mathrm{DMA}=$ aerial dry mass; $\mathrm{DMR}=$ root dry mass; $\mathrm{DMT}=$ total dry mass; IR $=$ index of robustness. ${ }^{1}$ The data represent the mean $\pm \mathrm{SE}(n=10) . \%=$ percentage in relation to the dose $0 \%(\mathrm{~g} / \mathrm{L})$ of the extract.

In the treatment with the $40 \%$ extract, the highest values were obtained for D ( $\left.4.85 \mathrm{~mm} \mathrm{plant}^{-1}\right)$, DMR (1.31 g plant $\left.^{-1}\right)$, and DMT (6.20 $\left.\mathrm{g} \mathrm{plant}^{-1}\right)$. Meanwhile, the treatment at $0 \%$ (control) presented a higher DMA value (4.94 $\left.\mathrm{g} \mathrm{plant}^{-1}\right)$.

A similar study developed by Marcolini et al. (2009), found that the density of Brachiaria decumbens Stapf. had a strong negative influence on the initial growth of Coffea arabica $\mathrm{L}$. In the coexistence of the coffee tree with 16 plants per square meter of grass, the dry matter reduction of the seedlings was $80 \%$. B. decumbens showed a $47 \%$ reduction in leaf area when it coexisted with coffee at four plants per square meter of grass, with higher densities yielding higher reductions in leaf area.

The aqueous extract of brachiaria grass significantly influenced most of the morphometric characteristics of eucalyptus plants evaluated in this experiment. According to research developed by Chou (1989), this grass contains compounds with allelopathic properties, such as ferric acid, p-coumaric acid, 2,4-dihydroxybenzene acid, vanillic acid, p-hydroxybenzoic acid, and p-hydroxyphenylacetic acid, which are phenols, with p-coumaric acid and p-hydroxyphenylacetic acid having the highest concentrations.

Kobayashi and Kato-Noguchi (2015), evidenced that an aqueous methanol extract of $B$. decumbens inhibited the growth of roots and shoots of cress (Lepidium sativum), lettuce (Lactuca sativa), timothy (Phleum pratense) and ryegrass (Lolium multiflorum) seedlings. The extract was then purified using chromatographic methods and a phytotoxic substance with allelopathic activity was isolated and identified by spectral analysis as (6R,9S)-3-oxo- $\alpha$-ionol. These results suggest that this compound may contribute to the allelopathic effect caused by the $B$. decumbens extract and may be in part responsible for the invasion and domination of $B$. decumbens. Therefore, this compound may play an important role in the phytotoxicity of the brachiaria species.

The regression analysis (Figure 1) shows a clear downward trend in the mean aerial dry mass (DMA) and total dry mass (DMT); in this case, this was due to the increasing concentrations of extract applied. 

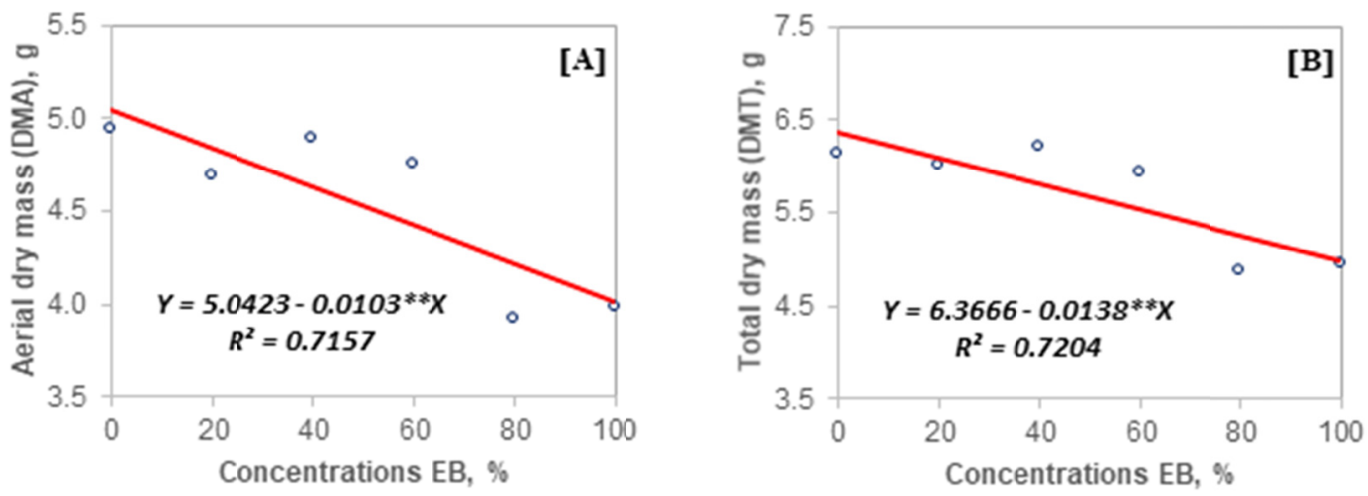

Figure 1. Aerial dry mass (A) and total dry mass (B) of Eucalyptus urograndis plants treated with increasing doses of Brachiaria decumbens (EB, \%) extract

Note. Graph with straight line adjusted to the experiment data. ** Significant at the $1 \%$ probability level.

Graphs A and B (Figure 1) show a linear effect of the brachiaria grass extract, whereas the quadratic effect was not verified. Together with the straight lines, it is adjusted regression equation: the approximate equation that links the levels of $\mathrm{X}$ (concentrations of EB in \%) to Y (aerial dry mass and total dry mass, in grams).

The increase in concentrations led to a decline in mean values and, consequently, the lines presented a downward behavior. Therefore, in the adjusted regression equations, the coefficient X (negative for both cases) expresses that the dry mass of the aerial part and total (DMA and DMT) decreased with ascending levels of brachiaria grass extract.

This information corroborates data presented in other studies. As in the case of $B$. decumbens, it was observed that the dry matter of some weeds had an inhibitory effect on the full development of Eucalyptus grandis plants (Souza et al., 2003). In a project developed by Bacha et al. (2016), distinct sowing and regrowth densities (above 2.6 plants $\mathrm{m}^{-2}$ ) of $B$. decumbens had a negative effect on the initial growth of $E$. urograndis.

Silva et al. (2017), when evaluating the allelopathic effect of $B$. decumbens root exudates on the early development of some pioneer forest species, also observed drastic reductions in leaf area, root dry mass, and the aerial part. However, for non-pioneer forest species, the allelopathic effect was shown to be less intense.

The brachiaria extract had a quadratic effect on the eucalyptus plants' stem diameter (D) and root dry mass (DMR), according to regression equations (Figure 2).
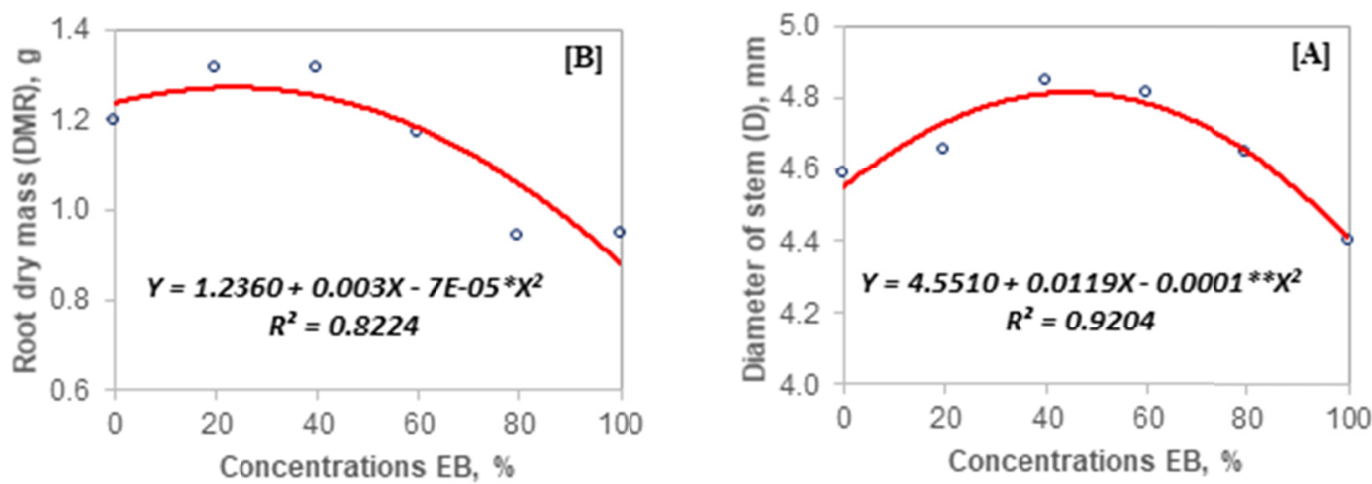

Figure 2. Diameter of stem (A) and root dry mass (B) of Eucalyptus urograndis plants treated with increasing doses of Brachiaria decumbens (EB, \%) extract

Note. Parable graph with adjusted second-order mathematical model. ${ }^{* *}$ Significant at the level of $1 \%$ and * 5\% probability levels.

According to the behavior of the parabola in Figure 2, which indicates a curvature related to this increase in the concentration of the extract (EB, \%), there is a significant quadratic effect on the morphological characteristics 
mentioned above. For the variable collecting diameter (Figure 2A), the curve reached the maximum value $(\mathrm{a}<0)$ of the quadratic function when brachiaria extracts were applied at a concentration of $59.5 \%(\sim 60 \%)$.

Thus, the diameter of the seedlings was beneficially influenced by an increase up to a $60 \%$ concentration of the extract. However, for concentrations greater than $60 \%$, there was a decline in the mean values due to an inhibitory effect. As a consequence, the parabola is pointed downward.

For the variable root dry mass (Figure $2 \mathrm{~B})$, the curve reached a maximum value $(\mathrm{a}<0)$ when the extract was applied at a concentration of $21.4 \%(\sim 20 \%)$; that is, up to $20 \%$ the extract influenced the variable dry mass roots in a beneficial way, and higher concentrations influenced it negatively.

Similar research, however, with native forest species, indicated that the aqueous extracts of brachiaria grass (Brachiaria spp.) and megathyrsus grass (Megathyrsus maximus (Jacq.) B. K. Simon \& S. W. L. Jacobs) at different dilutions and increasing concentrations (up to $10 \%$ ) did not have a significant effect on the development of angico-red (Parapiptadenia rigida (Benth.) Brenam). Therefore, even when treated with the aqueous extracts in question (brachiaria and megathyrsus grasses), the angico-red seedlings presented satisfactory development (Hartmann, 2015).

\section{Conclusions}

Considering the particularities of the present work, the extract of the aerial part of $B$. decumbens did not present an inhibitory effect on E. urograndis aerial part height (H) and robustness index (IR). However, there was a clear tendency towards inhibitory effects for extracts at concentrations above $20 \%$, which significantly influencing the variables root dry mass (DMR), aerial dry mass (DMA) and total dry mass (DMT). Therefore, these morphological characteristics were shown to be more sensitive to the treatments.

For the diameter of the stem (D), only concentrations above $60 \%$ had an inhibitory effect, hampering the full development of $E$. urograndis seedlings. Therefore, these assessments allow us to determine some aptitudes, especially when choosing forest species best suited for the implementation of agroforestry projects, or even those best suited for the regeneration and recovery of degraded areas.

\section{Acknowledgements}

This study was financed in part by the Coordenação de Aperfeiçoamento de Pessoal de Nível Superior-Brazil (CAPES)-Finance Code 001.

\section{References}

Assis, H. L. B., Cesarin, A. E., Nepomuceno, M. P., Salgado, T. P., \& Alves, P. L. C. A. (2015). Haloxifope-p-metílico para controle de Brachiaria decumbens na cultura do eucalipto. Cerne, 21(4), 553-560. https://doi.org/10.1590/01047760201521041831

Bacha, A. L., Pereira, F. C. M., Pires, R. N., Nepomuceno, M. P. \& Alves, P. L. C. A. (2016). Interference of seeding and regrowth of signalgrass weed (Urochloa decumbens) during the initial development of Eucalyptus urograndis (E. grandis $\times$ E. Urophylla). Australian Journal of Crop Science, 10(3), 322-330. https://doi.org/10.21475/ajcs.2016.10.03.p6995

Bonamigo, T., Fortes, A. M. T., Pinto, T. T., Gomes, F. M., Silva, J., \& Buturi, C. V. (2013). Interferência alelopática de folhas de cártamo sobre espécies oleaginosas. Revista Biotemas, 26(2), 1-8. https://doi.org/ $10.5007 / 2175-7925.2013 \mathrm{v} 26 \mathrm{n} 2 \mathrm{p} 1$

Chou, C. H. (1989). Allelopathic research of subtropical vegetation in Taiwan. IV. Comparative phytotoxic nature of leachate from four subtropical grasses. Journal of Chemical Ecology, 15(7), 2149-2159. https://doi.org/10.1007/BF01207445

Cremonez, F. E., Cremonez, P. A., Camargo, M. P., \& Feiden, A. (2013). Principais plantas com potencial alelopático encontradas nos sistemas agrícolas brasileiros. Revista Acta Iguazu, 2, 70-88.

Devore, J. L. (2006). Probabilidade e estatistica: Para engenharia e ciências (6th ed.). São Paulo: Cengage Learning.

Ferreira, D. F. (2010). Sisvar: Sistema para análise de variância de dados balanceados, Versão 5.6. Lavras: UFLA.

Gomes, J. M., \& Paiva, H. N. (2004). Viveiros florestais-propagação sexuada (3rd ed.). Viçosa, MG: UFV. 
Gonçalves, E. O., Petri, G. M., Caçador, D. A., Caldeira, M. V. W., \& Delarmelina, W. M. (2013). Crescimento de mudas de Acacia farnesiana (L.) Willd em substrato contendo diferentes materiais orgânicos. Ecologia e Nutrição Florestal, 1(3), 110-116. https://doi.org/10.13086/2316-980x.v01n03a02

Hartmann, K. C. D. (2015). Efeito alelopático das gramíneas exóticas Brachiaria spp e Megathyrsus maximum (Jacq.) B. K. Simon \& S. W. L. Jacobs sobre germinação, desenvolvimento e crescimento de mudas de Parapiptadenia rigida (Benth.) Brenan (Master's thesis, Universidade Estadual do Oeste do Paraná, Programa de Pós-Graduação em Conservação e Manejo de Recursos Naturais). Retrieved from http://tede.unioeste.br/handle/tede/700

International Allelopathy Society. (IAS). (2017). Constitution and Bylaws. Retrieved from http://allelopathysociety.osupytheas.fr/about

Kluthcouski, J., Cordeiro, L. A. M., Ceccon, G., \& Oliveira, P. (2013). Braquiária na agropecuária brasileira-Uma história de sucesso. In G. Ceccon (Ed.), Consórcio Milho-Braquiária (pp. 15-24). Brasília, DF: Embrapa Agropecuária Oeste. Retrieved from https:/www.embrapa.br/busca-de-publicacoes/-/publica cao/982597/consorcio-milho-braquiaria

Kobayashi, A., \& Kato-Noguchi, H. (2015). Phytotoxic substance with allelopathic activity in Brachiaria decumbens. Natural Product Communications, 10(5), 761-763. https://doi.org/10.1177/1934578X1501 000515

Larcher, W. (2000). Ecofisiologia vegetal (p. 531). São Carlos, SP: Ed. Rima.

Marcolini, L. W., Alves, P. L. da C. A., Dias, T. C. de S., \& Parreira, M. C. (2009). Effect of the density and of the distance of Brachiaria decumbens Staff on the initial growth of Coffea arabica L. seedligns. Coffe Sciense, 4(1), 11-15.

Molisch, H. (1937). Der einfluss einer pflanze auf die andere-Allelopathie. Jena: Gustav Fischer.

Oliveira Neto, S. N., \& Paiva, H. N. (2010). Implantação e manejo do componente arbóreo em sistemas agrossilvipastoril. In S. N. Oliveira Neto, A. B. Vale, A. P. Nacif, M. B. Vilar, \& J. B. Assis (Eds.), Sistema Agrossilvipastoril: Integração lavoura, pecuária e floresta (pp. 15-68). Viçosa, MG: Sociedade de Investigação Florestal.

Pimentel Gomes, F. (1987). A estatística moderna na pesquisa agropecuária (3rd ed.). Piracicaba: Potafos.

Pires, N. M., \& Oliveira, V. R. (2011). Alelopatia. In R. S. Oliveira Júnior, J. Constatin, \& M. H. Inoue (Eds.), Biologia e Manejo de Plantas Daninhas. Curitiba, PR: OMNIPAX. Retrieved from http://omnipax.com.br/ site/?page_id $=108$

Plevich, J. O., Gyenge, J., Delgado, A. S., Tarico, J. C., Fiandino, S., \& Utello, M. J. (2019). Production of fodder in a treeless system and in silvopastoral system in central Argentina. Floresta e Ambiente, 26(1), 1-12. https://doi.org/10.1590/2179-8087.051716

Rizzi, E. S., Pereira, K. C. L., Abreu, C. A. A., Silva, B. C. F. L., Fernandes, R. M., Oliveira, A. K. M., Matias, R. (2016). Allelopathic potential and phytochemistry of cambarazinho (Vochysia haenkeana (Spreng.) Mart.) leaves in the germination and development of lettuce and tomato. Bioscience Journal, 32(1), 98-107. https://doi.org/10.14393/BJ-v32n1a2016-29614

Santos, S. M. S., Cunha, D. V. P., Silva, R. A., Teixeira, E. C., \& Carvalho, F. D. (2017). Avaliação morfofisiológica em mudas de clones de eucalipto em viveiros comerciais na etapa de expedição. Revista Cultivando o Saber, 10(2), 238-250. Retrieved from https://www.fag.edu.br/upload/revista/cultivando o_saber/59a5b8a72e983.pdf

Silva, L. M. I., Silva, M. J., Rocha, J. S., Bianchini, E., Pimenta, J. A., \& Stolf-Moreira, R. (2017). Potential allelopathic effect of Brachiaria decumbens root exudates on neotropical tree seedlings. Theoretical and Experimental Plant Physiology, 29, 177-186. https://doi.org/10.1007/s40626-017-0093-y

Silva, L. R., Cruz-Silva, C. T. A., Barros, N. A. T., \& Olivetti, M. M. C. (2015). Alelopatia de espécies da família lamiaceae sobre o desenvolvimento de alface. Revista Cultivando o Saber, 8(1), 59-73.

Silva, V. P., Medrado, M. J. S., Nicodermo, M. L. F, \& Dereti, R. M. (2010). Arborização de pastagens com espécies florestais madeireiras-Implantação e manejo. Colombo, PR: Embrapa Florestas. Retrieved from https:/www.embrapa.br/florestas/busca-de-publicacoes/-/publicacao/858079/arborizacao-de-pastagens-com -especies-florestais-madeireiras-implantacao-e-manejo

Silveira, L., Secco, D., Santos, R. F., Muller, F., Lewandoski, C. F., \& Bueno, P. L. (2016). Potencial alelopático 
de citronela (Cymbopogon) sob a germinação, emergência e desenvolvimento inicial de plantas de cártamo (Carthamus tinctorius L.). Revista Acta Iguazu, 5(3), 25-38.

Simão, E. P., Neto, M. M. G., Queiroz, L. R., Cruz, J. C., Alvarenga, R. C., \& Silva, I. H. S. (2012). Avaliação de cultivares de braquiária entre renques de eucalipto. 49 Reunião Anual da Sociedade Brasileira de Zootecnia, Sociedade Brasileira de Zootecnia, Brasília

Souza, L. S., Velini, E. D., \& Maiomoni-Rodella, R. C. G. (2003). Efeito alelopático de plantas daninhas e concentrações de capim braquiária (Brachiaria decumbens) no desenvolvimento inicial de eucalipto (Eucalyptus grandis). Revista Planta Daninha, 21(3), 343-354. https://doi.org/10.1590/S0100-83582003 000300001

Toledo, R. E. B. (1998). Efeitos da faixa de controle e dos periodos de controle e de convivência de Brachiaria decumbens Stapf no desenvolvimento inicial de plantas de Eucalyptus urograndis (Unpublished Master's thesis, Escola Superior de Agricultura Luiz de Queiroz, Universidade de São Paulo, Brazil).

Toledo, R. E. B., Alves, P. L. C. A., Valle, C. F., \& Alvarenga, S. F. (1999). Manejo de Brachiaria decumbens e seu reflexo no desenvolvimento de Eucalyptus grandis. Scientia Forestalis, 55, 129-141.

\section{Copyrights}

Copyright for this article is retained by the author(s), with first publication rights granted to the journal.

This is an open-access article distributed under the terms and conditions of the Creative Commons Attribution license (http://creativecommons.org/licenses/by/4.0/). 